\title{
Zoning of Public Offices, Liberal Democracy and Economic Development in Nigeria
}

\author{
Christian Ezeibe Ph.D1 \\ Ifeanyi Abada Ph.D2 \\ Martin Okeke Ph.D ${ }^{3}$
}

\author{
Lecturer in the Department of Political Science, University of Nigeria, Nsukka Christian.ezeibe@unn.edu.ng \\ Senior Lecturer, in the Department of Political Science, University of Nigeria, Nsukka \\ Senior Lecturer in Department of Political Science, Nnamdi Azikiwe University, Awka, Anambra State
}

Doi:10.5901/mjss.2016.v7n3s1p328

\begin{abstract}
In the face of extreme political distrust among the different ethnic groups in Nigeria, this paper examines the implications of zoning public offices for liberal democracy and economic development. Data was sourced from interview of elder statesmen sampled from the six geopolitical zones in Nigeria, secondary documents and direct observation. The paper argues that the zoning principle is elitist. Hence, the abandonment of principle is anti-elitist and the political elites whose economic survival depends on the zoning arrangement will always rise to defend it. Frequently, the elites employ hate speech, blackmail and violence to defend zoning which has proved to be the easiest means to power and wealth in Africa. The then dominant political party in Nigeria, Peoples Democratic Party, used the zoning principle to reduce political, religious and ethnic tension from 1999 to 2015. The distortion of the zoning principle in 2010 after the death of President Yar'Adua led to a political chain reaction mostly expressed by loss of the presidential election by the ruling party in 2015. The then opposition party which is in charge of the new government has abandoned the zoning principle and disproportionally appointed Northerners into major public offices in Nigeria. Different ethnic groups based in the South-East and South-South have renewed calls for disintegration of Nigeria. This paper recommends that the new government should maintain the zoning principle among the six geopolitical zones in Nigeria to promote national stability and guarantee economic development.
\end{abstract}

Keywords: Zoning Public Office; Ethnic Groups; Democracy; Development; Religion

\section{Introduction}

Nigeria is home to more than 250 ethnic groups with diverse religions and cultures. Historically, we have Igalas, ljaws, Igbos, Urhobos, Itsekiris, Modakekes, Yorubas, Hausas, Fulanis, Nupes, Kanuris, Ogonis, Katafts, Tivs, Gwaris, Jukars, Edos, Ibibios, Efiks, Idomas, Jukuns, Birons, Agnas, Ogojas, and many more others except Nigeria (Ojelabi, 1970). These nations or city states, as the case may be, were independent states that traded with each other prior to British colonialism (Eleazu, 1977; Ake 1981). The idea of the Nigerian state arose out of concerted effort on the part of the British colonizers to fully integrate the African territories into the global capitalist economy. This integration aimed at unilateral administration of Northern and Southern protectorates as well as Lagos colony.

By 1960, the British colonizers felt it was no longer beneficial to continue colonization of Nigeria and they granted her independence. This arose out of both increasing agitation by the nationalists and negative impact of the Second World War on the British economy. For the colonial master who had bumped the distinct groups together as Nigeria, it was time to exit.

After the national independence, the Northerners (Hausa-Fulani) began to see political power as their birth right while civil service is for the Southerners (Igbos and Yorubas). Maila Sule once argued that Yoruba's are for commerce, Igbos are gifted with technology while the Hausa Fulani are destined to rule (Razor 19th October, 1993, 1). As these groups struggle to seize, consolidate and use state power for the interest of their ethnic group, Nigerians suffer. The experience of electoral violence, sectarian killing and civil war in Nigeria are illustrative. Achebe (1983:1) rightly noted that that "there is nothing wrong with the Nigerian people, atmosphere or water, the problem of Nigeria is simply and squarely leadership". Leaders emphasize the differences among Nigerians to intensify the destruct among groups and serve their economic interests. The level of political distrust is high such that Nigeria has organized two national conferences with limited success to address the national question between 2005 and 2014.

Despite the efforts of successive Nigerian governments to address the multi-headed problems of Nigeria since 
1960, political/representative inequality remains rife. From 1999 to 2015, the dominant political party, the Peoples Democratic Party (PDP) adopted the principle of zoning public offices to counteract the problem of political/representative inequality at state and national levels. For this purpose Nigeria was divided into the following six geopolitical zones:

1. North-West -Jigawa, Kano, Katsina, Kaduna, Kebbi, Sokoto, and Zamfara states

2. South-West -Lagos, Ogun, Osun, Oyo, Ondo and Ekiti states

3. South-East -Abia, Anambra, Ebonyi, Enugu and Imo states

4. North-Central-Benue, FCT, Kogi, Kwara, Niger and Plateau states

5. North-East-Adamawa, Bauchi, Borno, Gombe, Taraba and Yobe states

6. South-South -Edo, Delta, Bayelsa, Akwa-lbom and Rivers states

In 1999, President Olusegun Obasanjo (South Westerner) emerged under the auspices of PDP as a democratically elected President of Nigeria. The party respected the zoning principles to elect the Senate President and the Speaker of House of Representatives. The party also compelled President Obasanjo to respect the zoning principle in the appointment of the Secretary to the Federal Government and Head of Service of the Federation. Olisa Agbakoba, a Nigerian based social activist, observed that at a glance, the zoning principle seems to fit into the heterogeneous and federal nature of the Nigerian state, helping to accommodate all groups as much as possible and therefore reducing complaints of domination and/or marginalization (The Punch, 10 th June, 2011).

President Olusegun Obasanjo ruled for eight years (1999-2007) and handed over to a Northerner, President Musa Yar' Adua in 2007. Yar' Adua's death in May, 2010 truncated the zoning arrangement that was expected to keep the position of the President in the North for a period of eight years. After the death of President Yar' Adua, the then VicePresident, Goodluck Jonathan (Southerner) was sworn-in as the President. This power shift from the North to South in 2010 heightened mutual suspicion and the hatred between the various religious and ethnic groups. Meanwhile, the Northern elite had expected that PDP would nominate a Northerner for the office of the President for the 2011 Presidential election but the nomination of President Jonathan by the party announced the death of the zoning consensus. After President Jonathan was elected in 2011, the North felt short-changed by the party. This explains the unprecedented electoral violence that followed the 2011 Presidential election and the escalation of insecurity in Nigeria.

Ahead of the 2015 general election in Nigeria, the pace of Boko Haram (a terrorist group based in Northern Nigeria) attacks increased as the Northern political elites resolved to ensure that power shifts back to the North. All major opposition parties merged to form the All Progressives Congress (APC) to wrestle power from PDP and the South. In 2015, the new party fielded a North-West Presidential candidate and a South-West Vice-Presidential candidate while PDP fielded a South-South President and a North-West Vice-Presidential candidate. The APC won the 2015 Presidential election and since then have disregarded the zoning principles which informed the nomination of the President and VicePresident at the party primary election. This paper examines the implications of zoning public offices for liberal democracy and economic development in Nigeria.

\section{Theoretical and Methodological Considerations}

This paper argues that the political elites in Nigeria emphasize the zoning of public offices between federating units because it serves their economic interest. Frequently, these regional ethnic leaders are often called upon to represent their regions each time it was the turn of their ethnic group, region or geo-political zone to produce the occupant of any given position. Our analysis takes into cognizance all the three levels of analysis namely: individual, state and international system.

Observably, social inequality which moves with Western capitalism as its fulcrum prevails in Nigeria since hers independence in 1960. Meanwhile, power has not shifted away from the ruling class that emerged after 1960; rather power has continued to revolve around specific families in each region. Such families include the Nwodos and Chimes in Enugu state, Ubas and Okadigbos in Anambra state, Sarakis in Kwara state and the Laimidos and Kwankwasos in Kano state.

What seems evident in PDP is that the laws and rules are not followed or are manipulated to support the interests of powerful individuals and groups especially on the dimension of internal democracy (Liebowitz \& Ibrahim, 2013). This is true of the other parties in Nigeria and even in sub-Sahara Africa. It could therefore be held in dialectical logic and practically substantiated in science that the economic interest of the dominant class in each region determines the nature and dynamics of power shift between the federating units. Frequently, the interest involved in determining power shift would always be economical. So long as the abandonment of the zoning principle is anti-elitist, the political elites whose economic survival depends on it will make the polity ungovernable until their rights and privileges are restored. This is because behind this seeming equality of citizens enshrined in the 1999 Constitution of Nigeria lays a state that indirectly 
maintains the dominance of already dominant class over other citizens.

In this paper, we triangulated methods for data generation. We relied on face-to-face oral interview, documentary method and direct observation. We purposively selected 12 people for interview. We stratified Nigeria into six geo-political zones. Specifically, we interviewed 12 elder statesmen (2 from each geopolitical zone). Data were also sourced from textbooks, magazines, newspapers and academic journals dealing with zoning of public offices. The authors also observed the Nigerian polity and zoning behaviour for the past sixteen years. The paper utilized both explanatory and descriptive methods of analysis.

\section{What is Zoning of Public Office?}

Zoning is one of the manifestations of ethnic nationalism in Africa (Salawu \& Hassan, 2011). In common parlance, zoning of public office means sharing, rotating, shifting or pushing of political office(s) from one section to the other. It could be region based (from the North to South or East and West or vice versa). Zoning could be ethnic based (among the major ethnic groups) and or religion based (between major religious groups). Chuba Okadigbo, a former Nigerian Senate President, noted that political parties in Nigeria adopted the zoning formula to ensure a rotational presidency and other major offices. He justified that this practice was aimed at promoting unity, political stability and economic growth in Nigeria. He further remarked that zoning was expected to make all ethnic groups to feel as part of the federation and identify themselves with the Nigerian Constitution (Vanguard, $5^{\text {th }}$ April, 1989).

According to Nwala (1997), the decision was taken to address problems of hegemonism, marginalization and instability in the Nigerian polity. The six geo-political zones were to serve as the basis of power sharing in Nigeria for executive, bureaucratic, military and social offices. It also serves as the basis of locating infrastructure and industries as well as situating government units and departments. It is therefore seen as the sustainer of the Nigerian federalism. No wonder Author Nwankwo argued that "anyone who thinks that power will not shift in Nigeria under certain context (survival of various groups) is making a great mistake and an enemy to the Nigerian federalism" (Sunday Vanguard, $12^{\text {th }}$ September, 1993, 20). On the contrary, Banjo (2010) sees zoning as an undemocratic formula used by political parties to share power according to loosely-defined geographical zones that are not sanctioned by the electorates.

\section{The Roots of Zoning Public Offices in Nigeria}

Although the idea of adequate representation of different ethnic groups in the Republic has been recurring since 1960, zoning of political positions in Nigeria officially dates back to 1979. It was first expressed by the National Party of Nigeria in the internal nominations for prominent federal positions. However, the zoning of political offices became pronounced after the debate of the 1994/95 National Constitutional Conference (NCC) established by Decree No. (3) 1994 (FRN Gazette, 1994). The Conference resolved as follows:

- To pass resolutions and conclusions which shall form the framework for the good governance of Nigeria so as to guarantee freedom, equality, justice and opportunities for social, political, educational and economic participation and enjoyment;

- Establish a system of government in Nigeria with due regard for our national expectations and aspirations as a united indivisible federal entity;

- Preserve the unity and territorial integrity of the Nigerian state within an equitable framework;

- Guarantee the promotion of social, economic and political cohesion of Nigeria;

- Promote good government accountability and probity in public affairs;

- Identify areas and proffer solutions to public maladministration at any tier of government;

- Promote love, understanding and mutual respect among the citizenry and

- Acknowledge and encourage the harnessing of individual and collective initiatives aimed at the overall growth and development of the country.

- Propose a new constitution which shall be promulgated into law by the Provisional Ruling Council (Nwala, 1997:25).

Meanwhile, Ben Nwabueze, a Constitutional Lawyer, correctly observed that National Constitutional Conference took place in the immediate post-annulment of the June 12, 1993 election in which a Southerner emerged as the winner (Daily Champion, $8^{\text {th }}$ September, 1998). However, the annulment 1999 Presidential election was a major indication that the Northern elites are serious with imposing its political hegemony on South. In fact, it was political crises precipitated by the annulment of June 12, 1993 Presidential election that led to the convening of the 1994/95 National Conference. The 
think tank of the conference revealed serious inequalities in the distributions of political power and national resources in favour of the North and hence, adopted the idea of political offices zoning in Nigeria to secure Nigeria's federalism (Nwala, 1997). Therefore, one may conclude that it is a history of inequalities and sectional domination in the sharing of political power and national resources in Nigeria in favour of the North that marked the origin of the idea of zoning of political position(s). Although such a conclusion may be right, it does not explain how sharing of political power can trickle down to the grass-root people, secure federalism and democracy as well as guarantee development of Nigeria.

The 1999 Nigerian Constitution also emulated the zoning formula by prescribing the Federal Character principle in Section 14 (3). The Federal Character is about inclusion of the six geopolitical zones in the allocation of political and public sector appointments including the office of the President (Busari, 1989). Hence, zoning is the political name for the constitutional principle of federal character. The essence was to tame the ugly incidence of ethno-regional domination in all human endeavours in Nigeria (Nwala 1979). The zoning of political position also finds expression in quota system. Public universities in Nigeria emphasize quota system rather than success in qualifying examinations for admission. Quota system also plays a central role for employments in public institutions in Nigeria.

Although zoning principle is the most outstanding innovation of the 1994/95 National Constitutional Conference, President Obasanjo is arguably the father of zoning in Nigeria. In 1979, he was instrumental to the transfer of power to President Shehu Shagari (a Northerner). He repeated the act in 2007 by transferring power to President Umaru Musa Yar'Adua (a Northerner). Hence, the former President rightly argued that if properly perfected and implemented, zoning propels values such as integrity, ethnic and religious tolerance, cooperation and accountability. It kills ethnic chauvinism which forms the basis of political engagement in Nigeria.

\section{History of Zoning Public Offices in Nigeria}

\subsection{Zoning Formula from 1979-1983}

The zoning formula of the Second Republic was a convention in recognition of the need for adequate geographical spread by the National Party of Nigeria (NPN). At the federal level, the following offices were zoned: Party Chairman, President, Vice-President, Senate President, Deputy Senate President, National Secretary, Speaker and Deputy Speaker of the House of Representatives (NPN, 1983). The NPN acknowledged that zoning system stretches beyond the birth of the NPN to the days of the Constitution Drafting Committee (CDC). It was a recommendation of the Constitution Drafting Committee (CDC) on Presidential Election which the military government rejected. No doubt, this formula, if properly applied would be a possible solution to such political problems as choosing the country's leaders and hence, national integration. These recommendations were picked up by the NPN from the waste basket of the military and used to win the presidential election of 1979. The recommendation divided the country into four geographical zones namely - Zone One consist of Sokoto, Niger, Kwara, and Kaduna State; Zone Two consist of Kano, Plateau, Benue, Borno, Bauchi and Gongola States; Zone three- Lagos, Ogun, Oyo, Bendel and Ondo States; Zone four housed Anambra, Imo, Rivers and Cross-Rivers States. Later the zones were known as A which stood for 1 and B, C and D for 2, 3 and 4 respectively (Nwala, 1997).

The NPN adopted the zoning system, to assure Nigerians that irrespective of their ethnic background, their sons and daughters, all things being equal is assured of attaining the highest political office in the country. It was on the premise of zoning that in the 1979 general election, Alhaji Shehu Shagari from zone A emerged as the President; Dr. Alex Ekwueme from zone $C$ emerged as Vice-President, Dr. Joseph Wayas from zone D emerged as President of the Senate and Chief Akinloye from zone B emerged as the Speaker of the House of Representatives (FRN Gazette, 1994).

\subsection{Zoning Formula from 1991-1993}

The zoning formula in the general election of the Third Republic from 1991-1993 was imposed on the two major political parties authorized by the military government, namely, the Social Democratic Party (SDP) and National Republican Convention (NRC). The zoning pattern was worked out by the military government as a guide to the parties because there were much intra-party problems in the two parties. Arising from this, the General Ibrahim Babangida government perhaps did not trust the politicians to work out a workable formula that would provide meaningful political opportunities for the various components of the federation such that the greed of political power is not pursued at the expense of the nation itself. It was however not surprising that the elected persons never formed government as constitutionally required following the military annulment of the election. 


\subsection{Zoning Formula from 1999-2010}

The Fourth Republic was a multiparty system but the Peoples Democratic Party suppressed about 29 other political parties such that Nigeria seemed to be a one party state. This tendency sustained through rigging of elections kept the PDP in power from 1999 to 2015. However, the PDP equally adopted a zoning arrangement for attaining political offices including elective offices. Hence, the Constitution of PDP upheld the principle of balance and fair federalism, equitable revenue sharing formula. Article 27 of the PDP Constitution contains the observance of fair representation, power-sharing and federal character principles. It explained clearly that the party shall observe the principle of power sharing, rotation and federal character in selecting appointing or electing its officers at national level and reflect geographical group and cultural peculiarities in the state and local government, so as to give the diverse peoples of Nigeria opportunity to participate in the administration of the party and Nations (PDP Constitution, 1999).

Between 1999 and 2010 rule of the PDP in Nigeria, the zoning clause was implemented under the elective and appointive positions. Hence, this arrangement ensured that each of the six geopolitical zones produced at least one prominent National political officer. The the appointment of Ministers, Directors, Heads of Parastatals and Ambassadors also reflected the zoning formula. Competition was not ruthless as most elections were merely ritualistic. Where changes occurred as a result of incapacitation by death or impeachment, a successor was usually sorted for from the same zone from where the former occupant of such position emanated. It was however not surprising, for President Obasanjo to rule from 1999 to 2007 under democratic dispensation without fear of coup by the Northern dominated Nigerian Army.

In 2007, the zoning formula of PDP shifted the position of the President to North East; Vice-President to SouthSouth, Senate President to North-Central and the Speaker of the House of Representatives to South-West. Appointments of Ministers and Directors also followed this same convention. These arrangements were designed to last till 2015. Despite that the position of the Vice-President was zoned to the South-South, Nigeria faced more threats from SouthSouth (Niger Delta) secessionist militant groups under the democratic rule of President Yar' Adua (Ajero, 2009).

After the death of the President, Umaru Musa Yar'Adua in 2010, the PDP zoning arrangement was distorted. Debate ensued on whether Goodluck Jonathan would be sworn-in as an Acting President or a substantive President. While the Northern elites favoured the former title to enable the North to produce another President in 2011 to complete their eight years term in 2015 , the Southern elites favoured the latter title to swear-in the then Vice-President as a substantive President. Despite that most Northern elders were blowing the whistle of the country's collapse if PDP zoning formula fails, President Goodluck Jonathan was sworn-in as a substantive President in 2010, the Vice-President was zoned to the North-West, Senate President to the North-Central, the Speaker of House of Representatives to the NorthWest, Secretary to the Government of the Federation to the North-East and the Head of Service to the South-East. In 2011, the question was whether President Goodluck Jonathan would contest the 2011 Presidential election or not? This debate subsisted because PDP zoned the position of the office of the President between the North and South of Nigeria and each of these zones was supposed to hold the position for eight years, before the position will shift to the other region (Opeyemi, Siyaka \& Opeyemi, 2014). When President Goodluck contested and won the 2011 Presidential election, the problem of national security in Nigeria was heightened (Omodia, 2012). According to Awopeju, Adelusi \& Oluwashakin (2012), the North indeed made Nigeria ungovernable.

\subsection{Zoning formula from 2011 to 2015}

After the election of President Goodluck Jonathan in 2011, the zoning structure was adjusted. The President from the South-South, the Vice-President from the North-West, Senate Present from North-Central, Speaker of House of Representatives from the North-East, Secretary to the Government of the Federation from the South-East and the Head of Service from the South-West. Table 1 below compares the allocation of the various positions among the six geopolitical zones in Nigeria from 1999 to 2015.

Table 1: Zoning Distribution in Nigeria by Geopolitical Zones, 1999-2015

\begin{tabular}{|c|l|c|c|c|c|c|}
\hline S/N & Positions & $\begin{array}{c}\text { May 1999-May } \\
2007\end{array}$ & $\begin{array}{c}\text { May 2007 - } \\
\text { May 2010 }\end{array}$ & $\begin{array}{c}\text { May 2010- May } \\
2011\end{array}$ & $\begin{array}{c}\text { May 2011- May } \\
2015\end{array}$ & $\begin{array}{c}\text { May 2015- } \\
\text { present }\end{array}$ \\
\hline 1 & President & South-West & North-West & South-South & South-South & North-West \\
\hline 2 & Vice-President & North-East & South-South & North-West & North-West & South-West \\
\hline 3 & Senate President & South-East & North-Central & North-Central & North-Central & North-East \\
\hline 4 & Speaker, House of & North-West & South-West & South-West & North-East & North-Central \\
\hline
\end{tabular}




\begin{tabular}{|l|l|l|l|l|l|l|}
\hline & Representatives & & & & & \\
\hline 5 & $\begin{array}{l}\text { Secretary to Government of the } \\
\text { Federation }\end{array}$ & South- South & North-East & North-East & South-East & North-East \\
\hline 6 & Head of Service & North-Central & South-East & South-East & North-West & North-East \\
\hline
\end{tabular}

Source: Awopeju, Adelusi \& Oluwashakin, 2012:15, updated by the authors.

Table 1 above shows that the zoning formula was respected from 1999 to May 2010 under the watch of the PDP. The death of President Yar' Adua and consequent return of the position of the President to a Southerner from 2010 to 2015 represent a fundamental breach of the PDP's zoning principle (Kamal \& Bello, 2014). Arguably, the greatest effect of the breakdown of the formula was the PDP's loss of the Presidential election to an opposition party (APC) in the 2015 election. Religious intolerance, perpetual animosity among ethnic groups and geo-political zone heightened especially after the collapse of the PDP zoning arrangement in 2010. Observably, out of the sixteen years experience of Nigeria with democracy from 1999 to 2015, the North had held the position of the President for only two years while the South has been President for fourteen years.

Unsurprisingly, Boko Haram insurgency received the sympathy of most Northern political elites and its attacks skyrocketed during the administration of President Jonathan as over 90 percent of the their attacks were carried out during that period. In fact, large scale attacks by the group on police, prisons, army, politicians, schools, religious buildings, international institutions (United Nations Building in Abuja), markets and civilians in Nigeria occurred after the swearing-in of President Goodluck Jonathan. Boko Haram attacks killed over 10, 000 people and displaced over 1.5 million people in Nigeria between 2010 and 2014 (Eme, 2014). In 2013, the U.S. Department of State designated Boko Haram a foreign terrorist organization and by mid-2014, the militants had begun to acquire territories in Borno, Adamawa and Yobe states of Nigeria. Between January and May 2015, Boko Haram attacks killed more than 2,000 civilians (Peters, 2014).

The apparent inability of the Federal Government under President Goodluck to quench the Boko Haram insurgency was exaggerated mainly by the Northern political elites in order to pull down the government of President Goodluck. Hence, President Jonathan's administration was sabotaged in every front and frustrated out of office after the 2015 general election. The Northern elites have successfully intimidated the rest of Nigerians to restore the presidency back to the North. Northern elites employed all tricks including the use of hate speech and sectarian killings and post electoral violence to restore power back to the North. This trend was successful despite that out of the sixteen Presidents/ Heads of State which Nigeria has produced since her independence in 1960; ten emerged from the North while six were from the South. Table 2 shows the roots of the Presidents of Nigeria from 1960 to present.

Table 2: Distribution of Nigeria's Presidents /Heads of State by geopolitical zones

\begin{tabular}{|c|l|l|l|}
\hline S/N & Name of President & Geopolitical zone & Number of Years in Office \\
\hline $\mathbf{1}$ & Sir Abubakar Tafawa Balewa (Prime Minister) & North-East & 5 years +3.5 months \\
\hline $\mathbf{2}$ & Dr. Nnamdi Azikwe (Governor-General, then President) & South-East & 5 years +3.5 months \\
\hline 3 & Gen. Aguyi Ironsi & South-East & 6.5 months \\
\hline $\mathbf{4}$ & Gen. Yakubu Gowon & North-Central & 9 years \\
\hline $\mathbf{5}$ & Gen. Murtala Mohammed & North-West & 6.5 months \\
\hline $\mathbf{6}$ & Gen. Olusegun Obasanjo & South-West & 3 years+6.5 months \\
\hline $\mathbf{7}$ & Alhaji Shehu Shagari & North-West & 4 years +3 months \\
\hline $\mathbf{8}$ & Gen. Muhammadu Buhari & North-West & 1 year +8 months \\
\hline 9 & Gen. Ibrahim Babaginda & North-Central & 8 years \\
\hline 10 & Chief Ernest Shonekan & South-West & 3 months \\
\hline 11 & Gen. Sani Abacha & North-West & 4 years +7 months \\
\hline 12 & Gen. Abdulsalami Abubakar & North-Central & 1 year \\
\hline 13 & Chief Olusegun Obasanjo & South-West & 8 years \\
\hline 14 & Alhaji Musa Yar'Adua & North-West & 2 years +11 months \\
\hline 15 & Dr. Goodluck Jonathan & South-South & 7 May 2010 to May 2015 \\
\hline 16 & Gen. Muhammadu Buhari & North-West & May $2015-$ Present \\
\hline
\end{tabular}

Source: Opeyemi, Siyaka \& Opeyemi, 2014: 14. Updated by the author 


\section{Implications of the Abandonment of the Zoning Principle for Liberal Democracy and Economic Development in Nigeria}

The North-East, North-West and North-Central successfully allied with the South-West (the region that produced President Obasanjo from 1999 to 2007) to form the All Progressives Congress (APC) in order to wrestle power from the Peoples Democratic Party (PDP) and the rest of the South (South-East and South-South). This was done through the use of hate speeches in public domains. Fasoranti (2014) noted that rather than creating an enabling environment for rational discourse and contestation of ideas for the electorate to be able to make informed choices, many of the political actors were making inflammatory remarks to inflame and deepen the divisions within the country in order to make political gains. This public speech pattern noted among the two dominant political parties, PDP and APC, in the media, indicated that Nigeria's democracy is yet to move beyond the basics and would spell doom for the country if not watched.

After the APC government led by President Buhari was inaugurated on $29^{\text {th }}$ May, 2015, political appointments have neglected the zoning formula. Figure 1 shows the skewed appointment in favour of the North.

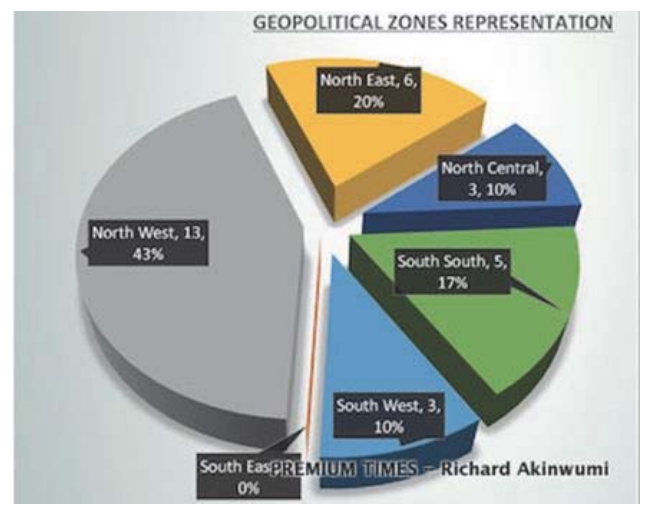

Figure 1: Distribution of key government officials done by President Buhari

Source: http://www.premiumtimesng.com/news/headlines/189117-outrage-grows-across-nigeria-as-buharis-lopsidedappointments-continue.html

Out of the first 30 appointments for key government officials made by President Buhari, 22 appointees were from the North while only 8 were from the South. Interestingly, none of the appointees was from the South-East. The appointments had demonstrated that Buhari's concept of one Nigeria is one that the South-East is alienated. This alienation of the South-East has contributed in making Nigeria one of the most religious and violent countries in the world. Meanwhile, President Buhari reiterated the illogical and vindictive rationale for this alienation during his first visit to the United States of America after he was sworn-in as the President of Nigeria. Buhari explained that it would amount to an injustice to treat those who voted for him and those who did not vote for him equally. Since the South-East did not massively vote for Buhari in the 2015 Presidential election, the geo-political zone should not expect much from his government (http://www.opinionnigeria.com/the-biafra-question-and-buhari-s-pledge-of-an-inclusive-nigeria). No wonder, Alhaji Mujahid Dokubo-Asari described Muhammadu Buhari's 2015 electoral victory as a gang up against the Niger Delta and South-East.

We observed that that the appointments of President Buhari were overwhelmingly lopsided, lacking in gender balancing and national inclusiveness. Hence, our respondents from the South-East and South-South described President Buhari as an ethnic jingoist, religious fundamentalist and Northern irredentist. The above description of Buhari was validated by his appointments which negate section 14 (3) of the 1999 Constitution that provides as follows:

The composition of the Government of the Federation or any of its agencies and the conduct of its affairs shall be carried out in such a manner as to reflect the federal character of Nigeria and the need to promote national unity, and also to command national loyalty, thereby ensuring that there shall be no predominance of persons from a few states or from a few ethnic or other sectional groups in that Government or in any of its agencies.

In defense of this lopsided appointment, the former Interim Chairman of the All Progressives Congress, Bisi 
Akande categorically stated that zoning is not part of APC. It is a PDP arrangement and APC will not practice it (http://www.premiumtimesng.com/news/top-news/183311-zoning-not-in-apc-agenda-bisi-akande.html). In a similar vein, the Chairman of the APC, John Odigie Oyegun averred that the recent appointments in Nigeria were merit based. This implied that the South-East lacked in good character, intelligence, drive, and vision to bring about the gains of democracy. The leadership of the APC argues that zoning encourages all forms of electoral malpractices (ballot box snatching, stuffing and manipulation of electoral results at collation centers) to maintain a specific region or zone in power (Omodia, 2012). Thus, it does not support an open contest between all constitutionally eligible options. Political parties therefore usurps the Nigerian citizens the right to vote and be voted for. The basic tenet of democracy is inherently and irreparably damaged by zoning. It enhances division rather than foster unity. It divides Nigeria into regions and tribes, and focuses on our differences. Observably, zoning formula does not support the basic tenets of liberal democracy which are imbibed in the 1999 Constitution of the Federal Republic of Nigeria. So long as the zoning arrangement places embargo temporarily, on a group of people on the basis of geopolitical zones from running for any elective office, it is a violation of the principle of human equality and dignity enshrined in the 1999 Constitution of the Federal Republic of Nigeria. The debate against zoning has gained prominence since PDP lost the presidential election. One of the most popular arguments is that zoning, quota system and the federal character principle sacrifices meritocracy in the shrine of mediocrity and or slaughters of excellence in the abode of incompetence. Again the leadership of the All Progressives Congress also argued zoning is merely used to serve the central purpose of the Nigerian state which is to divide up the country's oil wealth among elites at the expense of economic development.

Irrespective of the criticisms of the zoning principle in Nigeria, our respondents from the South-East and SouthSouth argued that the gap created by the abandonment of zoning is so wide that it cannot be filled by future appointments. They further argued that no amount of damage control will remove the current negative perception of the President in the South-East and South-South or assuage the injustice done by President Buhari's appointments.

Consequently, a rising sense of marginalization has emerged. Our respondents from the South-East and South South-South (home of the bulk of the oil producing states) observed that the poor state of infrastructural facilities, marginalization in federal appointments and other socio-economic issues explains the recent agitations for selfdetermination by members of the Movement for the Actualization of the Sovereign State of Biafra (MASSOB), Indigenous People of Biafra (IPOB), Movement for the Emancipation of the Niger Delta (MEND), Niger Delta People Volunteer Force (NDPVF), Niger Delta Peoples Salvation Front (NDPSF) and Niger Delta Vigilante Force (NDVF). The resurgence of these groups in the face of perceived and real alienation has contributed to reduce the growth in the oil sector which is the mainstay of Nigeria's economy. In the second quarter of 2015 growth in the oil sector declined by about 5.14 percent relative to the growth recorded in the corresponding period of 2014 (http://www.premiumtimesng.com/news/topnews/189026-nigerias-economy-records-2-57-growth-in-2nd-quarter-of-2015-says-nbs.html). Significantly, the Nigerian masses are poor amidst plenty. Despite the vast natural resources wealth in Nigeria, over 61 percent of the population lives in less than $\$ 1$ a day. In fact, the distortion of the zoning arrangement reversed the achievements apparently recorded by the Transformation Agenda under President Goodluck Jonathan and increased the rate of economic disparities between the North and South. Hence, 72 percent and 27 percent of Northerners and Southerners respectively live in poverty (Sergie \& Johnson, 2015). Meanwhile, the absence of relative parity among ethnic groups breeds violence and verbal clashes between these groups. It was arguably responsible for the 1966 pogrom against the Igbos in Northern Nigeria, the 1967-1970 Biafra and Nigeria civil war, Niger Delta militancy, Boko Haram insurgency, the 2011 post election violence in Nigeria, religious violence and the current secessionist threats by the South-East and South-South.

Although the zoning formula may appear elitist and anti-developmental, it has become unavoidable because it appeals to the people's emotions and helps to stabilize the polity. In the absence of zoning in Nigeria, most ethnic groups feel marginalized and political instability heightens. The instability that arises from the abandonment of the zoning principle undermines the infrastructural and institutional capacities of the Nigerian state to promote foreign trade and investments required for economic growth and development.

Again, the abandonment of the zoning principle has not ameliorated the incidence of corruption, conspicuous consumption, abuse of law and order that traumatize the Nigerian polity. More so, public fiscal indiscipline and persistent rise in price level which are the major factors that have adversely influenced economic development in Nigeria have remained (Uwakaeme, 2015).

Similarly, staffing of public institutions is essential for development. The observance of the zoning principle during staffing of public institutions in Nigeria makes the people to locate themselves in the society. Although the quota system is sustained largely became it serves the individual and collective interest of the men (leaders) who have held power, who have held and lost power or who have lost power and who seek to strike for balance for selfish ends, it also serve huge public interest. 


\section{Conclusion and Recommendations}

Nigeria is not the only federal state that has maintained merit and handwork as well as accommodated sectional interest to remain a global economic, political and ideological power. No doubt, the zoning arrangement promotes national cohesion and recognizes the right of the people to be a part of the system. The abandonment of the zoning arrangement has further exposed the Nigerian state to the risk of disintegration. The adoption of the zoning formula to counteract the problem of inter-ethnic distrust arising from ethnic and religious intolerance in Nigeria appears not to have succeeded. Despite that the zoning arrangement has not translated to firmer democratic institutions and sustainable development, it has helped to maintain national stability. This is because the zoning principle accommodates the interest of the multiethnic groups that make up Nigeria. Secondly, the successive ethnic leaders that emerged as national leaders in Nigeria support the zoning principle. In the face of the strong role of the state in economic development, the leaders of the major ethnic groups rely on zoning of public offices to access political power and wealth. This explains why these leaders use all necessary resources to defend the zoning system.

In the light of the above discourse and the dwindling global economic condition, this paper recommends that Nigeria should maintain the zoning principle until a sovereign national conference addresses the mounting problem of inter-ethnic distrust. This conference will enable each ethnic group to decide whether they wish to continue to federate or not.

\section{References}

Achebe C. (1983). The trouble with Nigeria. Enugu: Fourth Dimension Publishers.

Afigbo A. (1990). Background to Nigeria federalism, in M. Turi (ed) Nigerian federation: Accident or design. Darker: West Africa publishes.

Ajaero C. (2009). Victim of neglect. Newsletter, October.

Ake C. (1981). Political economy of Africa. Ibadan: Longman.

Awolowo O. (1968). Path to Nigerian freedom. Ibadan: University Press.

Awopeju A, Adelusi O \& Oluwashakin A. (2012). Zoning formula and the party politics in Nigerian democracy: A crossroad for PDP in 2015 presidential election. Research on Humanities and Social Sciences, 2 (4):11-19

Banjo L. (2010). Zoning of elective offices is destructive and fosters disunity. Retrieved from http://nigeriaworld.com/feature/publication/ banjo/031510.html on 20th May 2015

Busari OA. (1989). Federal character and social class, in P.P. Ekeh and E.E. Osaghae (eds) Federal character in Nigeria. Ibadan: Heinemann Educational Book Nigeria Limited.

Campbell J. (2011). Nigeria: Dancing on the brink. Maryland: Rowman \& Littlefield Publisher Inc.

Carl F. (1964). New tendencies in the federal theory and practice. London: Oxford University Press.

Eleazu U. (1977). Federalism and nation building: The Nigerian experience 1951-1964. London: Arthur Stockwell.

Eme O. (2014). Human cost of Boko Haram activities in Nigeria, 2004-2014. Germany: Lambert Publishers.

Etiozoni A. (1962). A paradigm for the study of political unification. World Politics. 15 (1): 44-74.

Fasoranti R. (2014). Nigeria preparing for war, not election. Silverbirdtv.com/news,

Federal Republic of Nigeria Official Gazette (1994). $2^{\text {nd }}$, May.

Ikejiani-Clark M \& Ikejiani O. (1986). Nigeria political imperative, desiderate for nationhood. Enugu: Fourth Dimension Publishers.

Kamal O \& Bello U. (2014). Democracy and succession problems in Nigeria: The fourth republic experience. An International Journal of Arts and Humanities, 3 (3): 47-60.

Liebowitz J \& Ibrahim J. (2013). A capacity assessment of Nigerian political parties. Democratic Governance for Development (DGD) Programme, UNDP, Nigeria

Marx K \& Engels F. (1968). Selected works. New York: International Publishers.

Nigeria Year Book 1983. (1991). Newswatch. March.

NPN Constitution. (1983). Article 21.

Nwala T. (1997). Nigeria path to unity and stability. Enugu: Novelty Industries Ltd.

Ojelabi A. (1980). A text of West African history, $1000 \mathrm{AD}$ to the present day. Ibadan: Educational Research Institute.

Omodia S. (2012). Election, governance and the challenge of national integration in the Nigerian fourth republic. British Journal of Arts and Social Sciences, 5(2): 307.

Opeyemi A, Siyaka M \& Opeyemi A. (2014). Power sharing conundrum and the challenges of 2015 general elections in Nigeria. International Journal of Development and Economic Sustainability, 2 (3): 9-21.

Peoples Democratic Party Constitution (1999). Abuja: PDP.

Peters, M. (2014). Western education is sinful: Boko Haram and the abduction of Chibok schoolgirls. Policy Futures in Education, 12(2). Retrieved from http://pfe.sagepub.com/content/12/2/186.full.pdf html on 1st February, 2016.

Salawu B \& Hassan A. (2011). Ethnic politics and its implications for the survival of democracy in Nigeria. Journal of Public Administration and Policy Research, 3(2): 28-33. 
Sergie M \& Johnson T. (2015) "Boko Haram". Council on Foreign Relations. Retrieved from http://www.cfr.org/nigeria/boko-haram/ p25739 on 11th July, 2015.

Uwakaeme O S. (2015). Economic growth in Nigeria: An empirical investigation of determinants and causal relationship (1980 - 2012). American Journal of Economics, 5(1): 9-20.

Wheare K. (1963). Federal government. London: Oxford University Press. 